\title{
Overcoming the procedures for obtaining a location permit for the Podravska high- speed road project
}

\author{
Bašić Marija ${ }^{1}$, Kranjčić Nikola ${ }^{1}{ }^{*}$, Jug Jasmin ${ }^{1}$ and Đurin Bojan ${ }^{2}$ \\ ${ }^{1}$ Faculty of Geotechnical Engineering, University of Zagreb, Hallerova aleja 7, 42000 Varaždin, Croatia. \\ 2 Department of Civil Engineering, University North, 42000 Varaždin, Croatia.
}

World Journal of Advanced Engineering Technology and Sciences, 2021, 03(01), 060-071

Publication history: Received on 10 July 2021; revised on 18 August 2021; accepted on 20 August 2021

Article DOI: https://doi.org/10.30574/wjaets.2021.3.1.0060

\begin{abstract}
Roads are important infrastructure facilities that enable traffic accessibility, i.e. they improve the quality of transport communication between people, goods and innovations. The Podravina high-speed road project was designed with the aim of developing Podravina and Slavonia and enabling a better connection between them and the rest of Croatia. Road construction is a complex process that requires a location permit before construction begins. This paper is written with the aim of presenting in detail the process of obtaining a location permit, which is preceded by obligatory preliminary work. Its complexity depends on the type of a road, its purpose and characteristics of the area through which a planned road passes. The Podravina high-speed road is the largest infrastructure project in that part of Croatia and therefore detailed preliminary work is required. This paper describes some types of preliminary work which include geological, geomechanical and climatic tests. The paper presents a project justification study, an environmental impact study, an environmental impact study, a construction and a technical study as well as a spatial transport analysis. Based on the chosen Podravina high-speed road route, a general design was created by using a road design software program "Platea".
\end{abstract}

Keywords: Preliminary work; Location permit; High-speed Road; General design; Podravina

\section{Introduction}

Podravska highway is a long-planned project that would improve the most isolated part of the Republic of Croatia. The planned Podravska expressway would relieve the current Podravina highway D2 from transit traffic and establish a better connection between Slavonia and Podravina with other parts of Croatia. For the expressway to be realized, it is necessary to obtain a location permit, which is preceded by preliminary works. Preliminary works in the procedures for obtaining a location permit include investigative works, a feasibility study, an environmental impact study, a trafficspatial study, and a construction-technical study.

The first official document obtained for the Podravka Expressway project is a spatial traffic study that was completed in 1989. In the subject study, the first variant of the route of the Podravska expressway was presented, which was taken over in 2003 and finalized in a construction - technical study. The final selected variant of the Podravska Expressway route passes through five Croatian counties, considering the preservation of their cultural and historical heritage, highly useful agricultural land, water wells and other significant assets of the area. The counties of Varaždin, KoprivnicaKriževci, Virovitica-Podravina, Osijek-Baranja and Vukovar-Srijem have adopted the final variant of the route of the Podravina expressway in their spatial plans. Considering the length of the route in question, the stage construction of the road in four phases was chosen.

\footnotetext{
* Corresponding author: Kranjčić Nikola; E-mail: nikola.kranjcic@gfv.unizg.hr

Faculty of Geotechnical Engineering, University of Zagreb, Hallerova aleja 7, 42000 Varaždin, Croatia.
} 
In this paper, all preliminary works in the procedures for obtaining a location permit, which were carried out for the Podravska Expressway project, are elaborated, and in the professional software for designing roads "Platea" a preliminary design is made, modeled on the final selected route variant.

\section{Study area}

The Podravska expressway is a planned integral part of the Podravina-Danubian road route on the route Ormož-Otok Virje-Varaždin-Virovitica-Osijek-Ilok, with a total length of 325 kilometers (Figure 1). The Podravina expressway would connect five Croatian counties as planned: Varaždin, Koprivnica-Križevci, Virovitica-Podravina, Osijek-Baranja and Vukovar-Srijem.

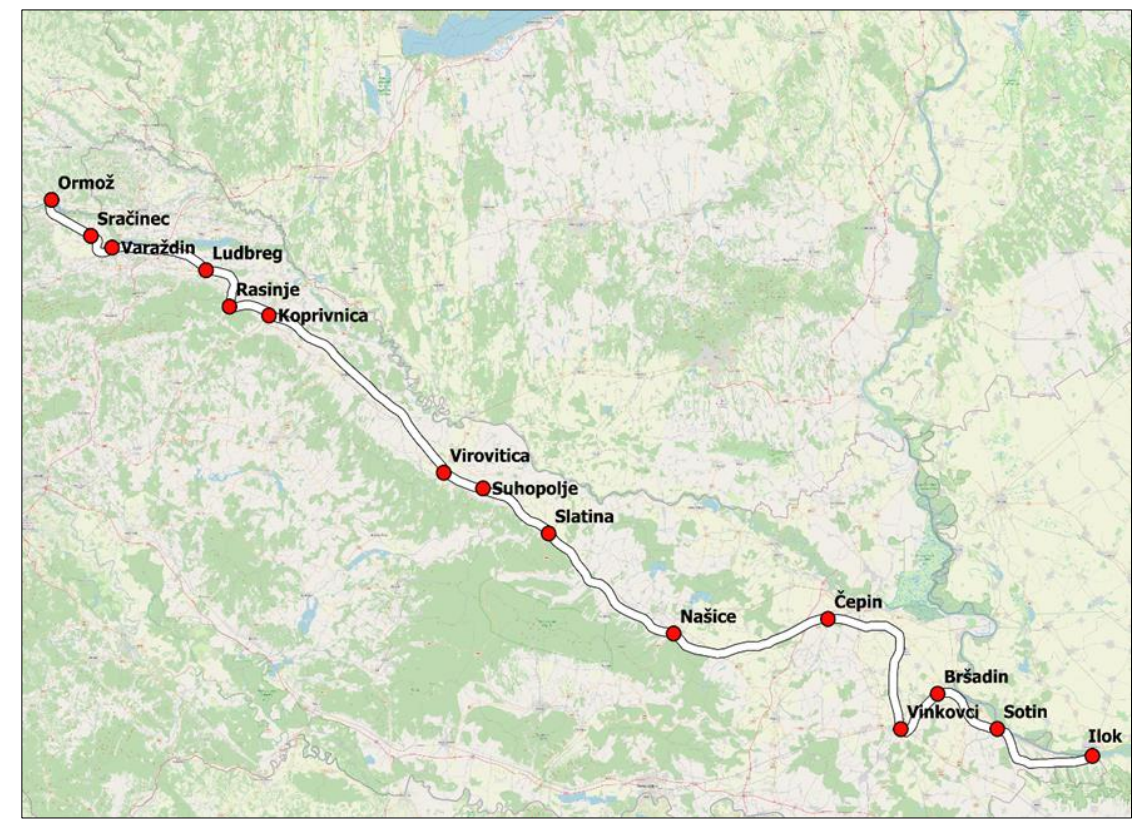

Figure 1 Planned expressway route

The purpose of the construction of the Podravina expressway is to contribute to important transport connections, which would result in accelerated and large economic development of the eastern part of Croatia. Apart from the connection of the Croatian territory, the Podravina expressway would be the most accessible connection for the Republic of Slovenia with the Republic of Serbia, and the international connection would be significantly improved. The construction of the highway would enable new investments, increase the number of jobs and accelerate the development of county centers.

The problem with the current Podravina highway is that it does not meet the needs of this gravity zone, ie the level of service is not equivalent to traffic density. The construction of the Podravina expressway would prevent the possible isolation of the Podravina regions of Croatia, which would occur if the Republic of Hungary built the planned expressway on its parallel territory with Podravina.

The average daily traffic of the Podravina expressway is planned for a minimum of 12,000 vehicles per day, with a projected speed of $100 \mathrm{~km} / \mathrm{h}$, which would significantly speed up the flow of traffic.

\section{Historical development}

The idea of the Podravska expressway dates back to the eighties of the twentieth century, when the first traffic-spatial study was launched. The study was completed in 1989 and was introduced in the then prepared spatial planning documentation. The Podravska Expressway corridor was divided into three sub-sectors with centers in Bolfan, Koprivnica and Virovitica. For many years after the first study, nothing significantly improved on the Podravska Expressway, and one of the reasons was the independence of the Republic of Croatia in 1991, which caused the redistribution of the center, new administrative bodies, and plans [1]. 
World Journal of Advanced Engineering Technology and Sciences, 2021, 03(01), 060-071

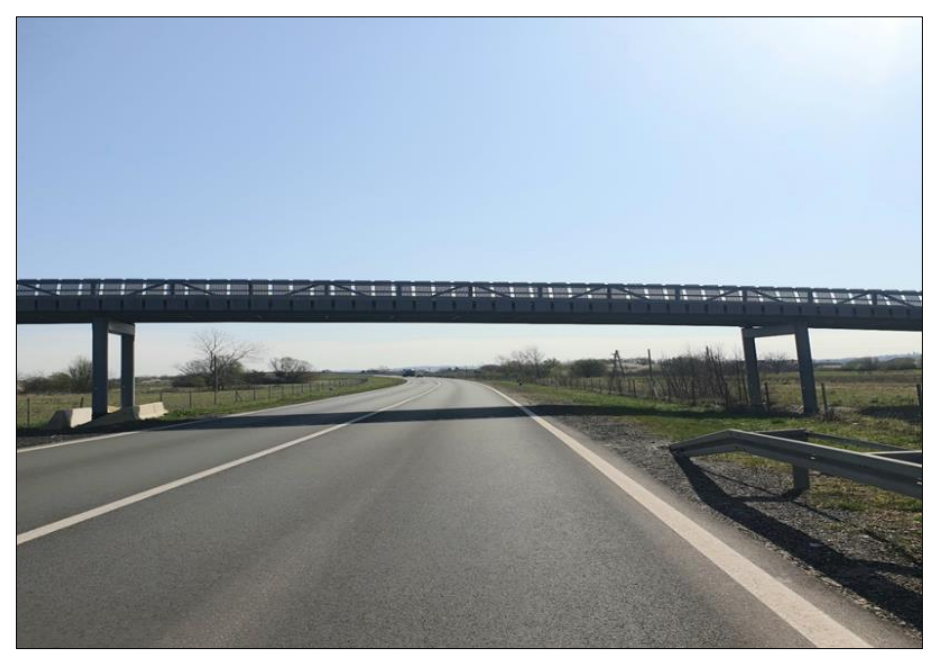

Figure 2 Southwestern bypass of the City of Varaždin

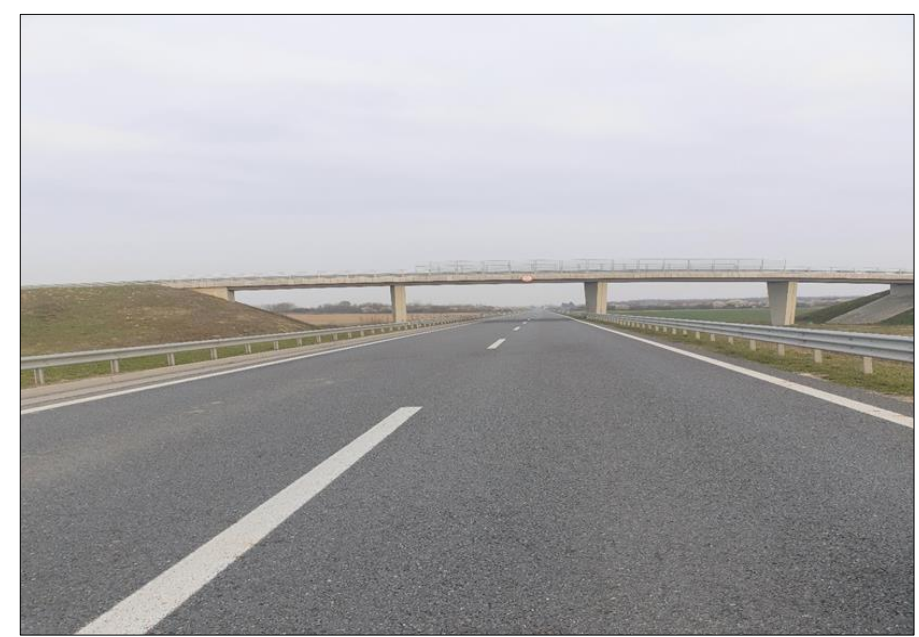

Figure 3 Expressway section Virovitica - Suhopolje

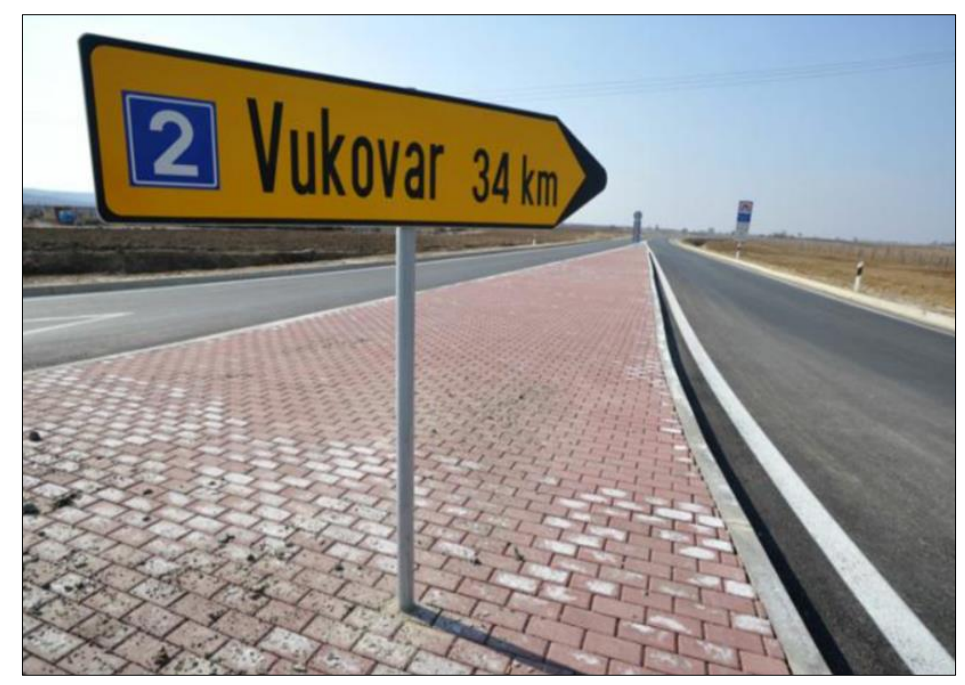

Figure 4 Bypass of the city of Ilok 
After the independence of the Republic of Croatia, the Podravska expressway is still planned, but since then each county has been carrying out pre-works separately for the part of the Podravska expressway that passes through their territory. The counties have in force spatial plans in which the territory through which the expressway is to be drawn is delineated. Virovitica-Podravina, Vukovar-Srijem and Varaždin counties have started construction of components of the future Podravska expressway, while Koprivnica-Križevci and Osijek-Baranja counties are still working on study and project preparation for construction [1].

To date, the following have been built from an integral part of the future Podravska expressway:

- $\quad$ southwestern bypass of the City of Varaždin, Hraščića - Kneginec (13 kilometers), 2007 (Figure 2).

- $\quad$ section Suhopolje - Virovitica (9.1 km), 2017 (Figure 3)

- $\quad$ Bypass of the City of Ilok (1.8 kilometers), 2011 (Figure 4)

\section{Pre-processing in procedures for obtaining a location permit}

A location permit is an act issued on the basis of the Physical Planning and Construction Act (OG 76/07, 38/09) in accordance with physical planning documents and special regulations on the basis of which every spatial intervention is carried out [2]. The location permit must be obtained for [3]:

- exploitation field,

- mining facilities and installations for the exploitation of hydrocarbons or geothermal water for energy purposes,

- designation of new military locations and military buildings,

- interventions in the area which, according to special regulations governing construction, are not considered construction,

- $\quad$ staged and / or phased construction of the building,

- complex intervention in space,

- construction on land, ie construction for which the investor has not resolved property relations or for which it is necessary to carry out the expropriation procedure and

- construction of buildings if the party so requests.

Before the start of road design, an investment study is prepared in which, based on the conducted research works, the economic and technical conditions and the justification and cost-effectiveness of road construction are considered. The investment study includes:

- feasibility study

- environmental impact study

- construction - technical study

- $\quad$ spatial traffic study and

- conceptual solutions.

After the approval of the investment study, which includes preliminary works for the procedure of obtaining a location permit, the design of the road can begin. Road design is performed in three phases [4]:

- conceptual design,

- $\quad$ main project and

- detailed design.

The final project of the road contains drawings and written and graphic necessary documentation.

\section{Research work}

\subsection{Research papers}

To start the design, the bases obtained on the basis of previous research works, such as geological, geotechnical, hydrological, geomorphological, meteorological, and geophysical and others, are needed. Investigative work needs to be done in advance in order to properly select the elements of the road. The scope of research works depends on the 
phase of the project, fewer tests are needed to prepare the study, while more tests are needed for the conceptual, main and implementation project. Investigative works and proper execution ensure the stability of the designed road. When choosing the position of the route, it is important to avoid unfavorable areas, which means prior research of the geological structure of the terrain and climatic and hydrological environmental conditions. In preparing the study, it is necessary to determine the characteristics of geological formations and the hydrological situation based on existing documentation and maps owned by geologists, surveyors, water administrations and others. The scope and sequence of investigative works are prescribed by the Ordinance on technical norms for the foundations of buildings for the preparation of preliminary and main projects [5]. For the preliminary design, it is necessary to drill one exploration well for every $1000 \mathrm{~m} 2$ and perform three field exploration activities such as: static or dynamic penetration sounding, experiments with a wing probe and piezometric testing [4].

Investigative work should be done thoroughly to prevent additional costs and delays in construction if the excavation of the foundation reveals unfavorable conditions and to prevent excessive subsidence and damage to buildings due to insufficient knowledge of soil characteristics.

\subsection{Geological examinations}

Geology is the science of the structure, dynamics and development of the Earth [6]. Geological surveys provide data on the type and origin of soil in the geological - mineralogical sense, soil characteristics such as stability, propensity to create landslides and soil types for which subsequent occurrence of water is assumed. Among the unfavorable geological phenomena are [4]:

- $\quad$ water-saturated areas such as wetlands, peatlands, lagoons and shoals,

- unstable areas such as moraines, sedges and sand deposits,

- areas that are not resistant to the effects of the atmosphere, such as areas made of clay, marl, shale, etc.,

- typical phenomena in high mountains, avalanches, debris, torrents and

- $\quad$ structural phenomena - cracks, steep faults and depressions.

During the survey, geologists, in cooperation with civil engineers, determine the scope of the survey, considering the available resources, the importance of the road, the amount of work and the type of soil. After reviewing the geological maps and touring the terrain, the geologists compile a report.

Geological tests carried out for the Podravina expressway on the section Suhopolje - Slatina established that the area where the future road will be built in the surface zone was built of deposits of marsh sediments, aeolian sand and dunes [7].

Table 1 Characteristic lithological profiles of the analyzed space

\begin{tabular}{|l|l|l|}
\hline Analyzed space & Slatina & Suhopolje \\
\hline Depth & $0-10,15 \mathrm{~m}$ sand & $0-10,15 \mathrm{~m}$ dusty clays 10,15 $-20 \mathrm{~m}$ clays \\
\hline Geological material & dusty sands, layers of clayey dusty sand & powders and sands \\
\hline Color & Yellow brown color & Brown and gray-brown color \\
\hline
\end{tabular}

\subsection{Hydrological study}

Hydrology is the science that studies the appearance, distribution, and outflow of water in time and space, as well as the chemical, biological and physical properties of water and its effects on the environment, including living organisms [8]. Hydrological tests are important to carry out before the construction of the road because they can significantly affect its construction and use. Before designing the road, it is necessary to make studies with the surface network of watercourses as well as with the network for groundwater drainage. Based on these studies, the required size of openings for bridges and culverts, the way of crossing the route over the area of high groundwater and the height of the level in the floodplain can be determined. Hydrological tests provide data on [4]:

- quantities of rivers and streams,

- high water heights and

- groundwater level. 
Data are collected from previously existing wells, bridges, major floods, culverts and the like.

Hydrological tests carried out for the Podravina expressway on the section Suhopolje - Slatina established that the planned road passes through the area of the Drava and Danube River basins. Significant watercourses in this area are Slatinska Čađavica, Javorica, Županijski kanal, Miškaroš, Dobrovica, Zlurada, Čađavica, Breznica Orešačka, Budančica and Jugova [7].

The Podravina expressway on the section Suhopolje - Slatina would intersect twenty watercourses and two canals of the first order in the towns of Brežnica and Čađavica, and the construction of bridges is planned for these areas. For channels of all rows with a width of the bottom of the riverbed up to $2.5 \mathrm{~m}$, it is proposed to make rectangular culverts of openings $2 \times 2$ or $2 \times 3 \mathrm{~m}$ and pipe culverts $\emptyset=160 \mathrm{~cm}$ [7]. From the flood hazard map, the planned Podravska expressway is in low to high probability of flood occurrence [7].

\subsection{Geomechanical tests}

Geomechanics is a branch of mechanics that studies the mechanics and physical properties of soil and rocks [9]. Geomechanical or geotechnical testing of soil materials and foundation soil is one of the necessary bases for the construction project of roads in the conceptual design phase. Contingencies and unplanned costs are most often caused by geotechnical conditions in the soil. The scope of geomechanical tests should be determined depending on the complexity of the project, ie the type of foundation structure, position and depth of construction and the like. Geomechanical tests determine the physical and mechanical properties of the material that will be formed by excavation or backfilling of the road body and the material located directly below the road body [4]. Geomechanical tests are carried out by field visit, sounding and field and laboratory tests.

For the purposes of testing, the following are measured: water permeability, shear strength, porosity coefficient, capillarity, internal friction or cohesion angle, soil granulometric composition, field and laboratory California bearing capacity index, maximum dry bulk density and specific soil mass and optimal moisture according to Proctor. Could calculate the allowable load and subsidence of the soil [4]. Geomechanical tests require:

- $\quad$ assessment of the mechanical quality of the soil on which it is necessary to build embankments,

- slope of the notch and embankment,

- $\quad$ proposal for placental material and

- usability of the notch material.

At the end of all geomechanical tests, the stability of the slope and notch of the embankment is checked, and the retaining and abutment walls are dimensioned.

\section{Hydrometeorological and climate tests}

The process of road construction and its use is influenced by meteorological and climatic conditions. By determining the hydrometeorological and climatic data for the planned construction area in advance, additional costs can be avoided, a longer construction period can be avoided, and the quality and service life of the road can be improved. Hydrometeorological data are obtained from the State Hydrometeorological Institute, which owns a network of meteorological stations [4]. If the construction area is not in the network of meteorological stations, the stations can be temporarily installed one year before the start of works. When it comes to the area of construction in soil sensitive to changes in humidity, the most important information for contractors is the average monthly values of evaporation and transpiration, ie the average temperature, wind and humidity. Of great importance to contractors is the hydrological or water balance, which shows the difference between precipitation and evaporation. The most suitable periods for earthworks are periods when the hydrological balance is negative [4]. Climatic influences such as temperature, precipitation, freezing depth, sunshine, and wind, need to be known in the first phase of design. Areas of strong winds and heavy rainfall that increase resistance to vehicle movement should be avoided. The priorities are always sunnier, drier and more stable areas for the construction of a more favorable road, because it is not necessary to perform protection against climate disasters. When building roads over a mountainous area, the area of the lowest height is chosen for the most favorable route. The performance of earthworks and dimensioning of the pavement structure depends on the depth of freezing, these data are determined from the maps of freezing depths made based on theoretical calculations or data collected by installing freezing indicators [4]. The area of the planned Podravska expressway is characterized as an area of fresh climate of continental type. The area is mostly flat, without large height differences, which results in the equality of climatic conditions. The mean annual air temperature is $10.6^{\circ} \mathrm{C}$, with the mean annual temperature varying from $9.3^{\circ} \mathrm{C}$ to $14.7^{\circ} \mathrm{C}$. The average monthly temperature varies from $-0.3^{\circ} \mathrm{C}$ in January which is the 
coldest month to $20.5^{\circ} \mathrm{C}$ in July the warmest month. The average monthly rainfall varies from $44.7 \mathrm{~mm}$ in February to $89.5 \mathrm{~mm}$ in June. Snow occurs in January and February and does not stay long on the ground, averaging 26.8 to 45 days. On average, the most common are light winds of 1 Beaufort (65\%) and 2 Beaufort (25\%), while winds of 3 Beaufort in the rarest cases, only $7 \%$. By predicting the change in air temperature for the planned project area in the period from 2011 to 2040 , it is expected to increase by $0.6^{\circ} \mathrm{C}$ in winter, to $0.8^{\circ} \mathrm{C}$ in summer, compared to the previously observed period. In the period from 2041 to 2070 , the temperature is expected to increase by $2^{\circ} \mathrm{C}$ in winter and by $2.4^{\circ} \mathrm{C}$ in summer. The changes in precipitation according to the forecast for the period from 2011 to 2040 will be the same or minimal, about $0.1 \mathrm{~mm}$ per day. Extreme weather conditions are possible for the projected area in the future, including an increase in the number and duration of heat strokes [7].

\subsection{Feasibility study}

The feasibility study contains the ecological, spatial, social, financial, market and economic justification of the planned investment for the selected solution, which contains the conceptual design, based on which the investment justification is decided and the procedure for issuing building permits is initiated [10]. For the observed section of the Podravska expressway on the route Suhopolje - Slatina, it is stated that the project was planned with the aim [7]:

- improvements of spatial and traffic elements of horizontal and vertical route management,

- increasing the level of safety and transport services,

- increasing the level of environmental protection,

- faster economic development of the region and its surroundings,

- increasing the level of quality of life in the region and its surroundings,

- better and faster connection of traffic routes in Croatia in the east - west direction.

The objectives are set in relation to the characteristics of the existing state road D2, given that each study should contain a comparative analysis of competing ventures, valorize them according to given criteria and extract data for decision making, which makes the feasibility study a complex investment study.

\subsection{Environmental studies}

The Environmental Impact Study (EIA) is an expert basis on the basis of which the environmental impact assessment is carried out, its evaluation and acceptability. The study contains all the necessary documentation, data, explanations and descriptions attached to the textual and graphic form, a proposal for assessing the acceptability of the project and environmental protection measures in relation to the project and, if necessary, an environmental monitoring program [11]. The construction of state roads is a project for which the implementation of an environmental impact assessment is mandatory. The mandatory content of the study includes [12]:

- description of the project,

- variants of the intervention solution,

- data and description of the project location and environmental data,

- description of the impact of the project on the environment, during the construction and / or use of the project,

- proposal of environmental protection measures and environmental monitoring programs, during the preparation of construction and / or use of the project, and

- the main assessment of the acceptability of the project for the ecological network if it has been determined in the previous assessment.

Environmental impact studies have been prepared for a few parts of the Podravska Expressway corridor. The environmental impact study for the section of the Podravska expressway: Rasinja junction - Koprivnica junction was prepared in 2009 and contains a description of the project and location, the environmental impact of the project, a plan for the implementation of environmental protection measures and environmental monitoring. The description of the project and the location includes basic information about the project and the location through which the planned route passes. The chapter on the impact of the project on the environment describes: biodiversity, geodiversity, surface and groundwater, air quality, noise level, economic features, infrastructure, cultural and historical heritage, sociological features and landscape. The impact of the project on biodiversity is classified according to the intensity of the impact, depending on how much the planned route of the Podravska Expressway includes biodiversity. There is no impact on geodiversity because there are no recorded geomorphological objects and phenomena in the planned route.

The impact of the project on surface and groundwater is low to moderate. The route of the Podravska expressway is planned in the area of the Drava River basin, which means that wastewater and liquid pollutants can reach the aquifer 
used for the water supply of the city of Koprivnica. On the part of the route, it is necessary to implement a strict regime with a high degree of pavement wastewater treatment, ie a closed drainage system [12].

Based on the results of the calculation of the spread of pollutants into the environment around the Podravska expressway, it is concluded that the intensity of the impact of the project on air quality is low. With a traffic density estimated by 2032, the calculated concentration of pollutants in the environment is significantly lower than the prescribed limit value of air pollutants for NOx and PM10. With the highest estimated value of traffic, the value of NOx and suspended particles is still significantly below the limit value, so it is not predicted that the Podravska expressway in the area along the route will significantly change the quality of the atmosphere [12].

The negative impact of the construction of the Podravska expressway is the increased noise level that occurs during the construction and operation phase. During the construction of the road, the noise is mostly created by construction machines and possible blasting, and in the exploitation phase, the noise is created by traffic on the highway. Noise during construction is more difficult to predict because it depends on the type of technology applied, while noise caused by traffic can be calculated very accurately depending on the technical characteristics of the road and the projected amount and structure of traffic. The maximum permissible noise level where people stay and work is considered, and in the ordinance, it is $50 \mathrm{~dB}$ for the night and $65 \mathrm{~dB}$ for the day. Based on the calculation, a low risk of the impact of the project on the noise level in certain zones was obtained [12]. The impact of the project on economic characteristics is more pronounced, especially on soil and agriculture. The impact on forests and forestry is mostly reflected in the permanent loss of forest area, by occupying forest areas with a planned road. The route passes through sixteen basic units of spatial division and shreds them further. The construction of the planned route also changes the forest water regime of the soil and the slopes of the route directly affect possible erosion processes. Another possible harmful effect on forestry are traffic excesses, which can cause harmful spills and fires. Forests are of great importance for the environment due to the impact on the climate, oxygen generation and purification of the atmosphere, so this planned intervention was assessed as moderately risky for forests. Also, there is a moderate risk of this intervention for game and hunting. The temporary impact is during road construction when wildlife is disturbed in their habitat and biological-ecological cycles. Temporary impacts are most pronounced during machine operation, earthworks, blasting and similar activities, when peace in habitats is disturbed by noise. The construction of the route should not have a permanent negative impact, except for the speed on the road, but with protection measures, ie the construction of prismatic mirrors, the construction of the road would be considered acceptable. When building a road, it is considered that the greatest impact will be on the soil and agriculture. Due to the route, a significant number of quality agricultural lands will be repurposed and cut. This is important for Podravina, where most of the population provides a livelihood through agriculture. On the planned route of the highway from the Rasinje junction to the Koprivnica junction, 70.76 hectares of agricultural land would be permanently lost. The area wide than 70 meters on both sides of the road must be repurposed due to soil pollution with harmful substances such as lead and cadmium. Dust and heavy metal particles from the road can accumulate in the soil. From agricultural land, they can reach groundwater by leaching or be introduced into human and animal nutrition through cultivated soil culture. Agricultural soils along the road are also subject to a high risk of liquids such as fuel, motor oils, antifreeze, and windscreen washers. It has been determined that due to permanent conversion, 8.89 hectares of forest land will be lost, as well as about $80 \%$ of valuable land by land use category [12]. The section of the Podravska expressway also has a significant impact on the infrastructure. The planned route would pass along the southern edge of the regional center for waste management in the northwestern part of Croatia, and it would be necessary to relocate the current road access to the regional center. The route also intersects the main gas pipeline, the JANAF corridor, three $110 \mathrm{kV}$ transmission lines, the corridor of the Republic of Hungary-Botovo-KoprivnicaKriževci-Dugo Selo railway and part of the route is in the water protection zone of the Ivanščak pumping station. For all infrastructure intersected by the planned route, an optional solution has been determined and guidelines that need to be followed during the design and execution of the project [12].

The impact of the intervention on the cultural and historical heritage is classified into direct and indirect influences. Direct impact is considered to be any physical destruction of cultural and historical objects, ie archeological sites within the envisaged zones of influence. The indirect impact is the violation of the integrity of the belonging space of the cultural property. In the area of the planned route, a high intensity of the impact on the cultural and historical heritage was assessed (Figure 5).

Figure 5 indicates in blue the directly endangered localities that are in the majority, namely: Rasinja - Gliboki potok, Vinsko polje, Lug, Pustakovec - west, Ogradec, Pustakovec - east, Obrški, Vratnec, Cerine, Podžupanjkovo, Mali Peteranšćak, Herešin, Stiske, Šalovica and Mađerina. Three indirectly endangered localities to which Novi Krči-Ograd and Goričko Polje belong are marked in red [12]. Podravska beza cesta will also have an impact on the existing population and activities, ie on sociological characteristics. The passage of the highway through Podravina assumes that there will be new forms of activities, revitalization of dead occupations and a larger number of employments of the local 
population. The construction of the road will reduce the number of agricultural lands, which will affect the primary activity in Podravina, but will open the possibility for new activities. Gradual population growth, a higher degree of urbanization, an increase in the value of real estate due to better mobility and the development of housing and economic development are also expected. The planned route will affect the conversion of the landscape, a total of 136.5 hectares. New edges will be created within forests, vegetation changes and the integrity of agricultural areas will be interrupted, and individual forests will be removed. Agricultural land with a total of 114 hectares will be the most degraded, followed by forests with 18.7 hectares. The planned corridor will grow a new, anthropogenic, structural element of the composition, mostly in line with the surface, and to a lesser extent within the overall high volume. The planned corridor will be a separate, isolated and dominant element of the landscape structure, which will not be connected with other natural parts of the landscape. The visual experience will change with the contrast of the new anthropogenic element with the surrounding natural landscape. The overall impact of the Podravska expressway was assessed as moderate, which means that the road will be noticeable and will attract attention in the landscape. The impact can be reduced by quality landscaping in accordance with natural and landscape laws in the project [12].

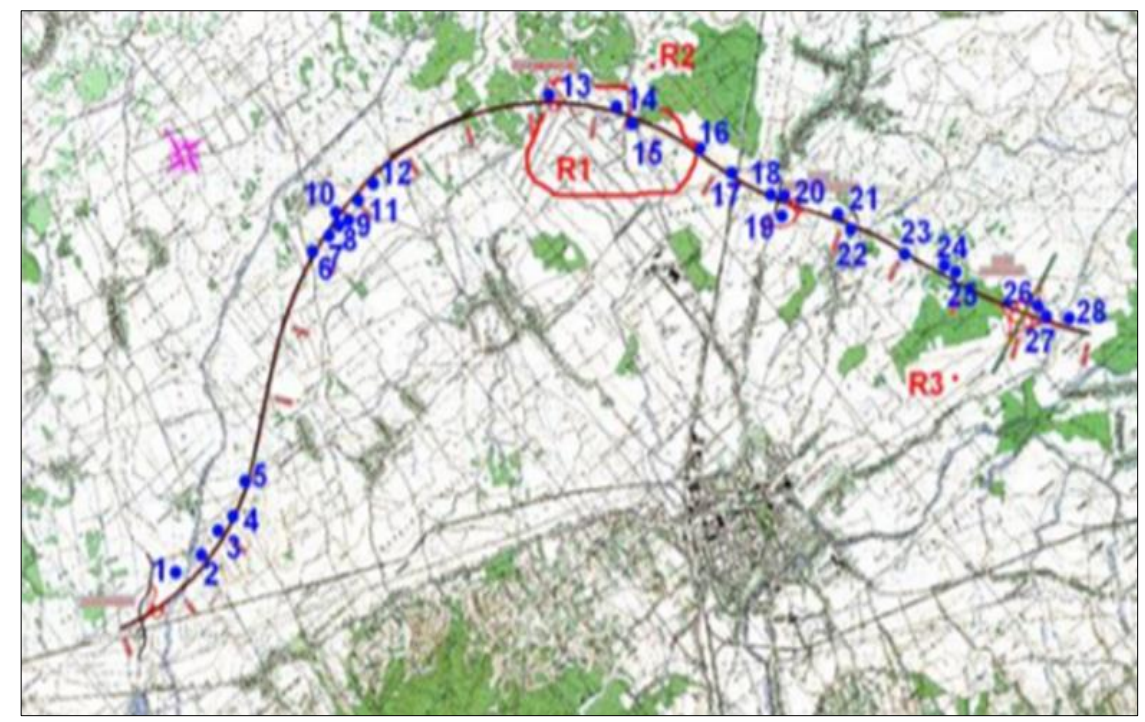

Figure 5 Cultural and historical heritage in planned route [12]

Table 2 Base technical elements from spatial-traffic study [13]

\begin{tabular}{|l|l|}
\hline Computational speed & for lowland parts: $\mathbf{1 0 0} \mathbf{~ k m ~ / ~ h , ~ f o r ~ h i l l y ~ p a r t s : ~} \mathbf{8 0} \mathbf{~ k m ~ / ~ h , ~ f o r ~ h i l l y ~ p a r t s : ~} \mathbf{7 0 ~ k m ~ / ~ h ~}$ \\
\hline Horizontal curves & $\mathrm{R}_{\min }<450 / 250 / 180 \mathrm{~m}$ \\
\hline Longitudinal slope & $\mathrm{i}_{\max }>5(6) \%$ \\
\hline Cross sections & Two or more levels \\
\hline Crossing distance & $3-10 \mathrm{~km}$ (in urban agglomerations min. $1 \mathrm{~km})$ \\
\hline $\begin{array}{l}\text { Transverse profile } \\
\text { lane width: } 3.5 \mathrm{~m} \text {, additional lane width for slow vehicles: } 3.0 \mathrm{~m}, \text { edge lane width: } 0.35 \mathrm{~m}, \\
\text { number of lanes: stage I: } 2 \text { (3), final: } 4 \text {, dividing belt: } 3,0 \text { (2,0) m, sidewalk: } 1,5 \mathrm{~m}, \text { road } \\
\text { belt: } 1,0 \mathrm{~m}, \text { buffer zone }(\text { depending on the purpose of the surrounding area) } 60,20, \text { and } 10 \\
\mathrm{m},\end{array}$ \\
\hline $\begin{array}{l}\text { The width of the land } \\
\text { belt under the road }\end{array}$ & $32-45 \mathrm{~m}$ \\
\hline
\end{tabular}

At the end of the study, a plan for the implementation and application of environmental protection measures and monitoring of the state of the environment is determined. For each component of the environment affected by the intervention, it is determined who the responsible holder of the measures is and what is the time for the implementation 
of the measures. When the route of the Podravska expressway is opened to traffic, it is necessary to establish a system of regular monitoring of the state of the environment in accordance with legal regulations. The system of regular monitoring of the state of the environment includes [12].

- monitoring of qualitative and quantitative compositions of aboveground and underground flora and fauna,

- monitoring the frequency and casualties of animals during traffic,

- reports on the state of the environment from Croatian highways

- supervision of solving problems related to the crossing of game and

- conducting a study of the impact of rainwater polluted pavement water on groundwater.

The proposal for the assessment of the acceptability of the project for the environment based on a study conducted for a part of the corridor of the Podravska expressway, section: junction Rasinje - junction Koprivnica was assessed as positive.

After taking all of this into account, in Table 2 are summarized necessary and planned parameters for expressway.

\section{Results}

Based on all conditions presented in Table 2, figure 6 presents road route situation, figure 7 presents one part of longitudinal slope and figure 8 presents one part of transverse profiles. All solutions were prepared in "Plateia" software package.

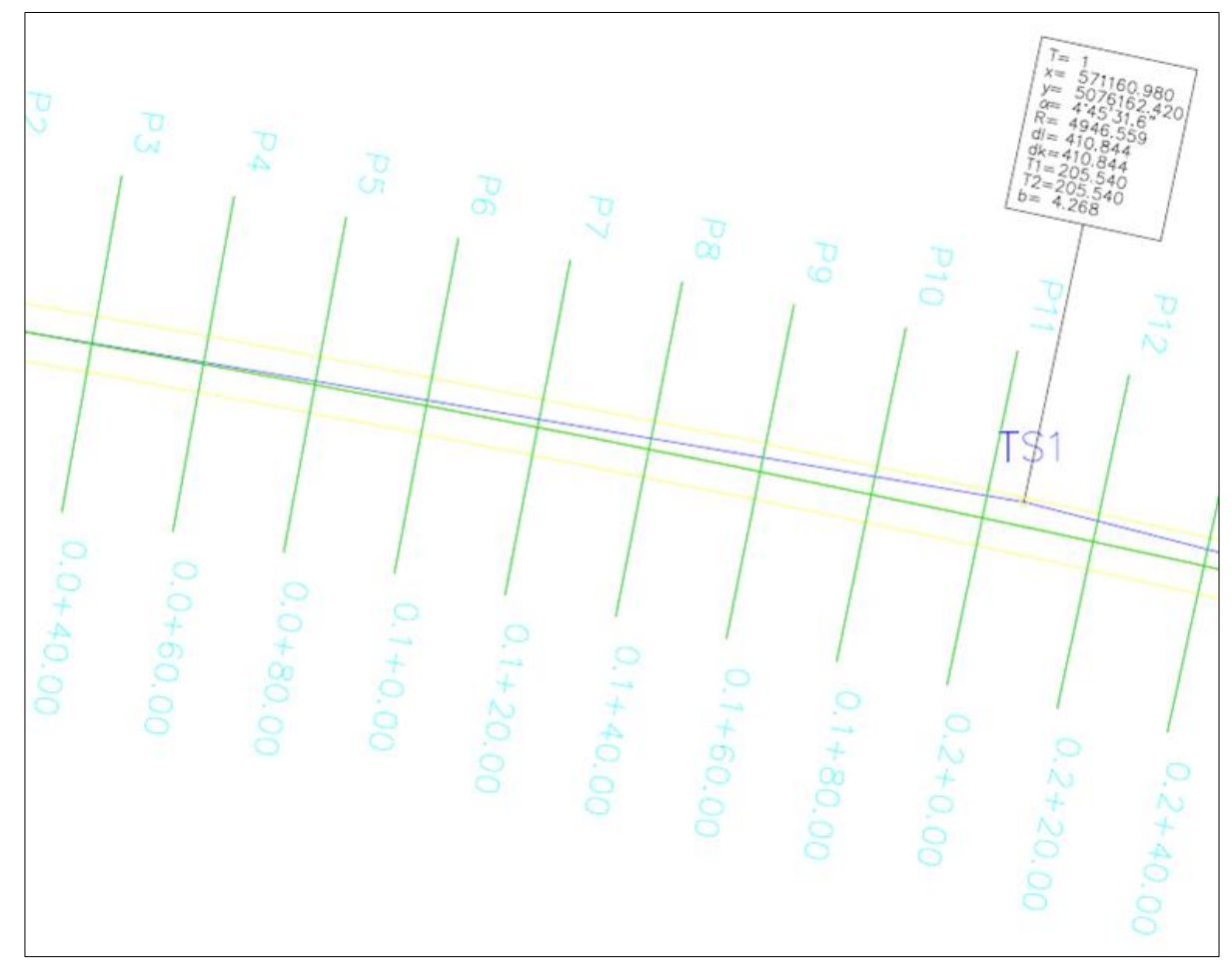

Figure 6 Road route situation 
World Journal of Advanced Engineering Technology and Sciences, 2021, 03(01), 060-071

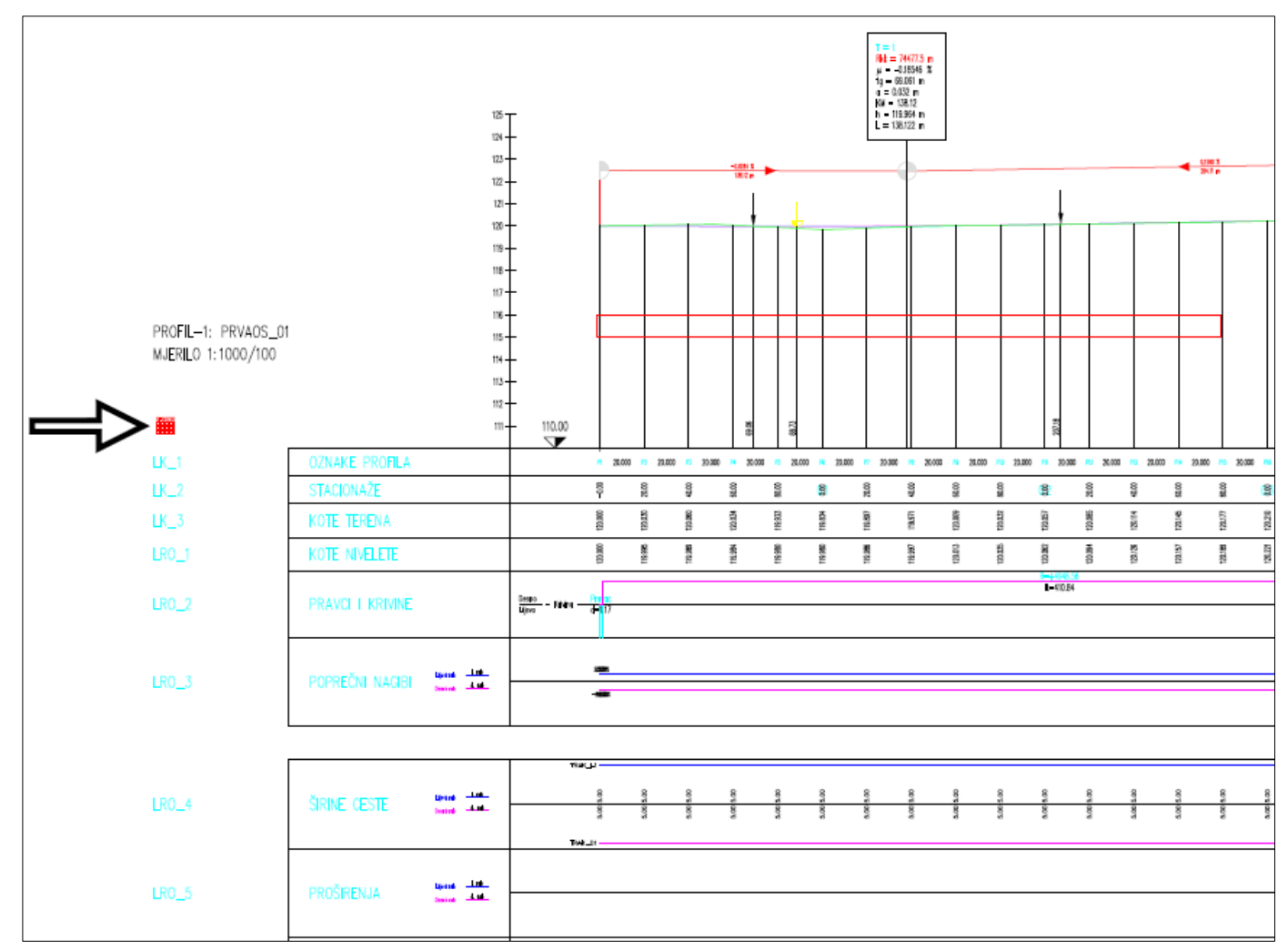

Figure 7 One part of longitudinal slope

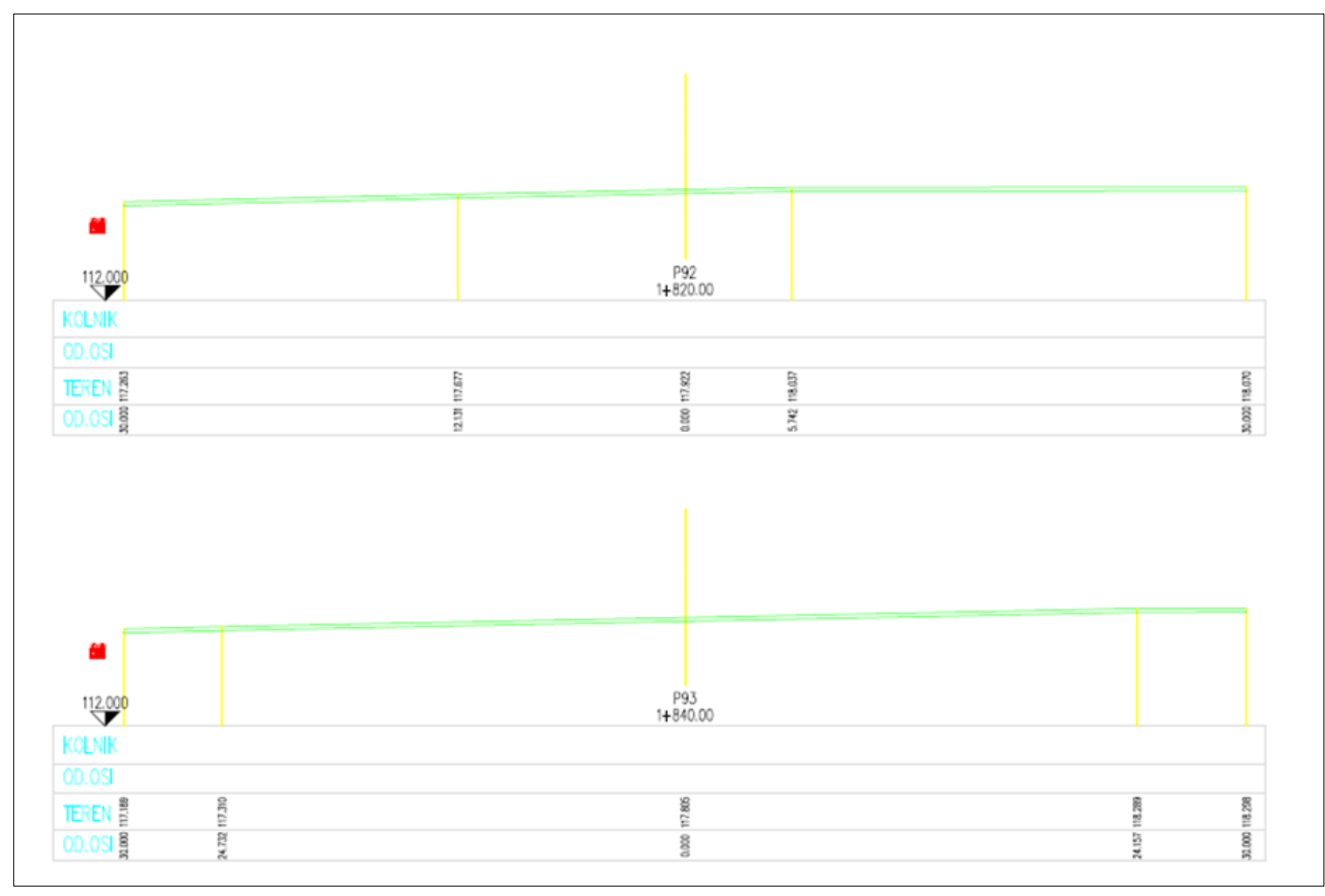

Figure 8 One part of transverse profile

\section{Conclusion}

The Podravska expressway is the largest infrastructural project in the Podravina area, which due to its complexity required detailed implementation of pre-works in the procedures for obtaining a location permit. Before obtaining a 
location permit, the first step is to justify the construction of the road, only when the reasons for justification are acceptable, can further preliminary work be continued. The key reasons for the construction of the Podravina Expressway were to encourage faster economic development of the region, increase traffic safety and services, relieve the Podravina highway, better and faster connection of Croatian traffic routes in the east-west direction and increase the quality of life in Podravina and surroundings. Compared to other roads in the Republic of Croatia that have already been built, several preliminary works have been carried out for the Podravska expressway in the process of obtaining a location permit, because the idea of the project dates back to 1985. In the meantime, during the past thirty years, there has been a redistribution of space due to the independence of the Republic of Croatia, and each newly formed county has carried out pre-works separately. Of all the preliminary works carried out for the Podravska expressway, environmental impact studies are the best processed documents that combine most of the required data. So far, a large part of the necessary documentation for the Podravska expressway has been obtained by each county. Three components of the future expressway have been built, and a faster and more efficient construction process is expected in the coming years.

\section{Compliance with ethical standards}

\section{Acknowledgments}

Authors would like to thank anonymous reviewers on their comments which improved the quality of the article.

\section{Disclosure of conflict of interest}

Authors declare no conflict of interest.

\section{References}

[1] Modern traffic - a condition for the development of Koprivnica.

[2] Law on Physical Planning and Construction. National newspapers. 2007. No. 76/07. [7/23/2007]

[3] Republic of Croatia, Ministry of Physical Planning, Construction and State Property. Location permit.

[4] Dragičević V, Rukavina T. Lower road structure. Zagreb: Faculty of Civil Engineering, University of Zagreb. 2006.

[5] Ordinance on technical standards for the foundation of buildings. National newspapers. 1990. No. 15/1990.

[6] Jurak V. Engineering Geology II. Zagreb: University of Zagreb, Faculty of Mining, Geology and Petroleum Engineering. 1998.

[7] Summary of the Environmental Impact Study, Podravska Expressways, section: Suhopolje - Slatina.

[8] Žugaja, R. Hydrology. Zagreb: Faculty of Mining, Geology and Petroleum Engineering; Geomechanics. 2015.

[9] Feasibility study.

[10] Environmental impact assessment of the project.

[11] Environmental Impact Study, Podravska Expressway, Section: Rasinje junction - Koprivnica junction.

[12] Construction - technical study of Podravska expressway.

[13] Spatial - traffic study. 